\title{
A Study on Awareness of Trained Teachers in relation to Information and Communication Technology
}

\author{
Nabin Thakur, \\ Ph.D. Research Scholar, Dept. of Education, Regional Institute of Education, NCERT, Bhubaneswar, Orissa, \\ India.
}

\begin{abstract}
This study was undertaken to study the level of ICT awareness among the trained teachers, to compare the level of ICT awareness among male and female as well as rural and urban trained teachers. The data was collected by self made questionnaire form in which thirty different secondary schools five from urban and five from rural of each three districts in West Bengal. Ten secondary trained teachers were allowed to administer the questionnaire from each school and the questionnaire was administered personally for each teacher. In that way all total three hundreds trained teachers participated to administer the questionnaire wherein fifty questions were pioneer and each question was carrying one mark. Based upon the scores of questionnaire, five categories were used like 1-10 very poor, 11-20 poor, 21-30 average, 31-40 good and 41-50 very good. To analyse the data Frequencies, Percentage, Mean, Standard Deviation (S.D.) and ' $t$ ' test were used. Result revealed that there was overall the level of ICT awareness was poor, there was no significant difference in the level of ICT awareness among the male and female trained teachers and there was a significant difference between the urban and rural trained teachers.
\end{abstract}

Keywords: ICT, Awareness, Trained Teachers

\section{Introduction}

Education is the 'third eye' of an individual, it gives insight into all affairs, it teaches how to act justly and rightly, it assists to realize the true significance of life, it eliminates darkness and smash illusion, it increases our fame, makes us cultured and pure, nourish us like a mother, directs us to the proper path, guides us to reach our destination. It is a very socially oriented activity and quality education has traditionally been associated with strong teachers having high degrees of personal contact with learners. An appropriate knowledge base is essential for creating powerful learning environments and for an adequate provision of supporting instructional material. In the process of transforming information to knowledge, the teacher plays an important part. Teaching is a process in which the teacher and students create an interactive environment. Technology is one of the way through which the teachers and students create an interactive environment in teaching learning process and it requires major improvements in education. It only possible when one uses the technology with maturity and competency. Information and Communication Technology (ICT) is being considered as the technology of having far reaching consequences in the field of education. It consists of three words Information, Communication and Technology. Information refers to any representation of knowledge such as facts, data or opinions in any medium or for including textual, numerical, graphic, narrative or audiovisual forms. Communication is the process and transferring information from a sender to a receiver with the use of a medium. Technology is the practical form of scientific knowledge or the science of application of knowledge to practical. Information and Communication Technology implies the knowledge, skills and understanding needed to exchange information verbally or non-verbally through speech, action or any electronic machine such as telephone, cellular phones, fax, radio, television, video, computer, e-mail etc. in addition to these network, hardware and software, satellite systems, videoconferencing etc. also come under.

Nowadays, teaching is becoming one of the most challenging professions in India where knowledge is expanding rapidly and much of it is available to students as well teachers at anytime and anywhere. As teacher education is primarily directed towards preparing teachers, the quality of teacher education depends on the teacher trainee's abilities and skills. The N.C.F. 2005 had also highlighted the importance of ICT in school education and it also stated that "ICT if used for connecting children and teacher with scientist working in universities and research institutions would also help in demystifying scientist and their work". Therefore, teachers have to accept the demands of modern world and modify their old concepts and methods according to the needs of learners, otherwise the teachers will become out-dated in the coming future and it will deteriorate the quality of education. There is widespread belief that ICT can and will empower teachers and learners for teaching-learning processes to develop their creativity, problem-solving abilities, informational reasoning skills, communication skills, and other higher-order thinking skills. ICT is not only used to enhance learning but also important for a teacher to be comfortable using to ensure that students get the full advantages of educational technology. Teaching with technology is different than teaching within a typical classroom. Teachers must be 
trained in how to plan, create, and deliver instruction within a technological setting. It requires a different pedagogical approach. According to Geer and Sweeney (2012) in order to use technology effectively, teachers need to be trained in using technology and they need to develop a good understanding of it. Teacher candidates need opportunities to practice effective technology integration strategies in supportive contexts during the B.Ed. course, teachers also need opportunities to learn about new technologies and ways to integrate them effectively in their classroom. Consequently teacher educators must acquire fresh knowledge of ICT before they can prepare their teacher trainees to meet the demands and challenges of the 21 st century.

\section{Review Of Related Literature}

Information and communications technology (ICT) in education is the meting out of information and its communications amenities and features that variously support teaching, learning and a range of activities in education. It has given a new dimension and a new layer to Education. The use of ICT in Education has really given an approach to teaching-learning process. The use of ICT in education provides itself to more studentcentered learning settings. But with the world moving rapidly into digital media and information, the role of ICT in education is becoming more and more important and this importance will continue to grow and develop in the 21 st century. In education ICT is the support material in the hands of the human resource which involves in the educational process in order to enhance the quality of education.

Dash (2007), remarked that information and communication technology is an important instrument, which can transfer teacher-centered, book-centered learning environment into a rich student-centered environment. This new learning environment developed by ICT, called Interactive Learning Environment. According to Jaiswal (2011), the teacher education system empowered by ICT-driven infrastructure can have a great opportunity to come up to the centre stage and ensure academic excellence, quality instruction and leadership in a knowledge-based society. This era of pervasive technology has significant implications for higher education. Technology allows students to become much more engaged in constructing their own knowledge. Conole (2004), found that about the actual positive impact of teaching and learning in higher education by using ICT. Jaffer, Ng'ambi and Laura (2007), found in their study that ICT had a key role to play in higher education as one of the strategies for addressing teaching and learning concerns. One of the main applications of the ICTs in higher education is teaching and learning based on these new technologies. Vajargah, Jahani and Azadmanesh (2010), found that for educational purposes ICTs can be used to support teaching and learning as well as research activities including collaborative learning and inquiring.

ICT makes education easier. Oye, Shallsuku and Iahad (2012), revealed in their study that that the use of ICT would make education system more effective for university undergraduate learners. It has brought revolution in education field. It is widely used effectively in current education system all over the world. ICT is one of the effective medium to impart education and it has become an exhortation in Indian education system. Cross and Adam (2007), and Bhattacharya and Sharma (2007), found that ICT eliminated time barriers in education for learners as well as teacher. It eliminates geographical barriers as learners can log on from any place. Plomp, Pelgrum and Law (2007), found that ICT could be used to remove communication barriers such as that of space and time. Therefore, teacher must access knowledge via ICT to keep pace with the latest developments.

Education is a process of human enlightment and empowerment for the achievement of a better and higher quality of life. Teaching is an ever changing profession. The field of education is expanding each year as advancement is made in technology and brain based research. To keep pace with the changing world, teachers must have current knowledge and skills of educational technology. The emergence of ICTs as learning technologies has coincided with a growing awareness and recognition of alternative theories for learning. Wang, McPherson, Hsu and Tsuei (2008), found in their study that teachers needed to attain more ICT skills to introduce ICTs before their students as well as to develop global awareness. Swamy (2010), found in his study about sound Internet awareness and competence among high school students and teachers. Adebowale (2012), found that only a small percentage of teachers possess a high level of awareness on ICT. Sasikala (2010), found in the study that there was no significant difference between Male and Female B.Ed students in their ICT awareness. Gulhane (2011), revealed that there was no significant difference between the theoretical and application awareness in the concept of ICT among male and female teacher trainees. Khedekar and Magre (2012), found that there was no significant difference in awareness about Information and Communication Technology of Secondary students with respect to Gender. Muthuchamy (2010), found in his study that students studying in rural and urban schools differed significantly in their perceptions towards ICT. Beena and Mathur (2012), found that the role of ICT in transforming teaching and learning and seeks to explore the awareness of teacher educators about use of information and communication technology for effective teaching learning process and how this will impact on the way programs will be offered and delivered in the teacher training institutions. 
Teacher education programs can facilitate improvements not only in students' technology skills but also in their beliefs and intentions regarding integrating technology into instruction. Technology training directly affects preservice teachers' self-efficacy and value beliefs, which in turn influence their student-centered technology use. New technologies have provided new possibilities for the teaching profession. However, teacher educators and teacher trainees have to learn how to use these new technologies in the classroom situations. Garrison and Anderson (2003), suggested that information and communication technologies (ICTs) can and do play a number of roles in education. These include providing a catalyst for rethinking teaching practice and improving the quality of teaching and learning. Yuen, Law and Wong (2003), found that ICT improves the quality of education by facilitating learning by doing, real time conversation, delayed time conversation, directed instruction, self-learning, problem solving, information seeking and analysis, and critical thinking, as well as the ability to communicate, collaborate and learn. Price and Oliver (2007), found in their study that preconceived ideas about mappings between technology characteristics and teaching-learning practices may need to develop. Plomp, Pelgrum and Law (2007), found in their study that in order to improve the pedagogy, teachers needed training on ICT which was motivating the students as well as the teachers. Elizabeth (2010), fond in her study that a teacher should know about technology, pedagogy and content for using them effectively in day-to-day classroom teaching

Eng (2005), found that the positive effects, impact and consequently a need for more in-depth of ICT on learning in the future. Yusuf (2005), found that the field of education had been affected by ICTs, which had undoubtedly affected teaching and learning. Kay (2006), revealed that the use of ICT in teacher education had the positive influence. Rathnabai (2007), found in her study that the ICT in teaching learning process enhanced the teaching and learning which in turn provided the quality education. Brown, McCormac and Zimmermann (2009), found in their study that the measurable impacts and effectiveness of ICT on students and teachers. Rajasekar and Dineshan (2013), ICT is a magic term in the field of education, it includes the use of technological devices for simplifying teaching-learning process. Possessing the knowledge of ICT is really the need of the hour. Especially as a teacher, the need of ICT knowledge is very much required for B.Ed. students in order to carry out the process of teaching and learning smoothly.

\section{Rationale of the Study}

One of the greatest challenges facing teacher education today is preparing good quality teachers for an ever-changing world. Teacher trainees are the key components in any system of teacher education. Unless they are trained we cannot expect any qualitative change to come out of the system of teacher education. ICT is a powerful tool for problem solving, conceptual development and critical thinking that helps to make the learning process much easier for the teacher trainees. Effective ICT contribute solutions to the problems in the daily classroom teaching. The present study was an attempt to find out the awareness about information and communication technology among the trained school teachers. Many studies on information and communication technology had been taken up. In West Bengal context an effort was made to find out the awareness of trained teachers in relation to information and communication technology.

\section{Statement of the Problem}

The present study was stated as

"A Study on Awareness of Trained Teachers in Relation to Information and Communication Technology in West Bengal"

Conceptual framework

Information and Communication Technology (ICT):

It consists of three words Information, Communication and Technology. Information refers to any representation of knowledge such as facts, data or opinions in any medium or for including textual, numerical, graphic, narrative or audiovisual forms. Communication is the process and transferring information from a sender to a receiver with the use of a medium. Technology is the practical form of scientific knowledge or the science of application of knowledge to practical. Information and Communication Technology implies the knowledge, skills and understanding needed to exchange information verbally or non-verbally through speech, action or any electronic machine such as telephone, Fax, radio, T.V. and Video, computer, e-mail etc.

\section{ICT Awareness of Trained Teachers:}

Means the use and knowledge of digital technology, communication tools, networks to access, manage, integrated, evaluate and create information in order to function in a knowledge society by the teachers who were B.Ed. trained. In the present study the ICT awareness was assessed on following components such as knowledge about computer, Internet, Electronic Mail (E-mail), World Wide Web (WWW), Broadcasting Technology (Radio and Television), associated human interactive materials that enable the secondary trained teachers to employ them for wide range of teaching learning processes in addition to personal use, overall ICT. 


\section{OBJECTIVES OF the study}

The study was conducted to achieve the following objectives:

To study the level of ICT awareness among the trained teachers.

To compare the level of awareness about ICT among male and female trained teachers.

To compare the level of ICT awareness among rural and urban trained teachers.

\section{HYPOTHESES}

There would be poor level of ICT awareness among the trained teachers.

There would be significantly no difference in the level of ICT awareness among the male and female trained teachers.

There would be significantly no difference in the level of ICT awareness among the rural and urban trained teachers.

Delimitations of the Study

The study was delimited to 300 trained secondary school teachers among thirty schools, fifty teachers from five urban and fifty teachers from five rural schools from each three district such as Malda, North Dinajpur and South Dinajpur of West Bengal.

Methodology

The present research was a descriptive survey type study.

Sampling

The present study, trained school teachers of West Bengal were the population and 300 trained secondary school teachers of Malda, North Dinajpur and South Dinajpur district were selected purposively.

Table-1 Distribution of sample in three districts

\begin{tabular}{|l|l|l|l|l|l|l|}
\hline $\begin{array}{l}\text { Name of the } \\
\text { districts }\end{array}$ & $\begin{array}{l}\text { Urban } \\
\text { school }\end{array}$ & $\begin{array}{l}10 \text { teachers from } \\
\text { per school }\end{array}$ & $\begin{array}{l}\text { Rural } \\
\text { school }\end{array}$ & $\begin{array}{l}10 \text { teachers from per } \\
\text { school }\end{array}$ & $\begin{array}{l}\text { Total } \\
\text { schools }\end{array}$ \\
\hline Malda & 5 & 50 & 5 & 50 & 10 & 100 \\
\hline $\begin{array}{l}\text { North } \\
\text { Dinajpur }\end{array}$ & 5 & 50 & 5 & 50 & 10 & 100 \\
\hline $\begin{array}{l}\text { South } \\
\text { Dinajpur }\end{array}$ & 5 & 50 & 5 & 50 & 10 & 100 \\
\hline All total & Urban and Rural schools 30 & Urban and Rural Teachers 300 & \\
\hline
\end{tabular}

Tool

The following tool was used for this study

Questionnaire form

For collection of data on awareness of trained teachers in relation to ICT in West Bengal, researcher employed self made questionnaire form. It included information and knowledge about computer, Internet, Electronic Mail (E-mail), World Wide Web (WWW), Broadcasting Technology (Radio and Television), associated human interactive materials that enable the secondary trained teachers to employ them for wide range of teaching learning processes in addition to personal use, overall ICT. In questionnaire all total fifty questions were pioneer and each question was carrying one mark.

To calculate the level of awareness related to ICT, five categories were used. Based upon the scores of questionnaire, categories were 1-10 very poor, 11-20 poor, 21-30 average, 31-40 good and 41-50 very good.

\section{Procedure of Data Collection}

After preparing the questionnaire form, the researcher visited thirty different secondary schools five from urban and five from rural in each three districts such as Malda, North Dinajpur and South Dinajpur in West Bengal. Ten secondary trained teachers were allowed to administer the questionnaire from each school and the questionnaire was administered personally for each teacher. In that way all total three hundreds trained teachers participated to administer the questionnaire.

Statistical Techniques

The collected data were analysed through application of required statistical techniques i.e. Frequencies, Percentage, Mean, Standard Deviation (S.D.) and ' $t$ ' test.

Analysis and Interpretation

The first objective was to study the level of ICT awareness among the trained teachers. The result has been shown in the following table. 
Table- 2 Level of ICT awareness among the trained teachers.

\begin{tabular}{|l|l|l|l|}
\hline S1.No. & Level of ICT Awareness & Frequency & Percentage (\%) \\
\hline 1 & Very Poor & 12 & 4 \\
\hline 2 & Poor & 162 & 54 \\
\hline 3 & Average & 103 & 34.33 \\
\hline 4 & Good & 06 & 2 \\
\hline 5 & Very Good & 17 & 5.66 \\
\hline Total & 300 & 100 \\
\hline
\end{tabular}

Table 2 shows that $4 \%$ trained teachers having very poor, $54 \%$ having poor, $34.33 \%$ having average, $2 \%$ having good and $5.66 \%$ having very good level of ICT awareness. Overall the level of ICT awareness is poor among the trained teachers.

The second objective was to compare the level of awareness about ICT among male and female trained teachers. The result has been shown in the following table.

Table-3 Level of ICT awareness among the male and female trained teachers.

\begin{tabular}{|l|l|l|l|l|l|l|l|}
\hline \multicolumn{4}{|l|}{ Male Trained Teachers } & Female Trained Teachers & Degrees of freedom (df) & t- value \\
\hline M1 & N1 & S.D.1 & M2 & N2 & S.D.2 & \multirow{2}{*}{298} & 1.349 \\
\hline 20.07 & 170 & 8.37 & 18.87 & 130 & 7.04 & \\
\hline
\end{tabular}

Table-3 shows that the computed value of " $t$ " i.e. 1.349 is smaller than the critical table value of ' $t$ ' with 298 degrees of freedom at five percent and one percent level of significance is 1.97 and 2.59 respectively. Hence, it is not significant up to $5 \%$ and $1 \%$ level of significance. Therefore, there is no significant difference in the level of ICT awareness among the male and female trained teachers.

The third objective was to compare the level of ICT awareness among rural and urban trained teachers. The result has been shown in the following table.

Table- 4 Level of ICT awareness among the rural and urban trained teachers.

\begin{tabular}{|l|l|l|l|l|l|l|l|}
\hline \multicolumn{2}{|l|}{ Urban Trained Teachers } & \multicolumn{2}{l|}{ Rural Trained Teachers } & Degrees of freedom (df) & t- value \\
\hline M1 & N1 & S.D.1 & M2 & N2 & S.D. 2 & \multirow{2}{*}{298} & \multirow{2}{*}{7.864} \\
\hline 22.79 & 150 & 6.71 & 16.31 & 150 & 7.55 & & \multirow{2}{*}{} \\
\hline
\end{tabular}

Table-4 shows that the mean value of urban trained teachers in relation to ICT awareness is higher than rural trained teachers. The critical table value of ' $t$ ' with 298 degrees of freedom at five percent and one percent level of significance is 1.97 and 2.59 respectively. The computed value of " $t$ " is 7.864 which is greater than the critical table value. Hence, it is significant up to both $5 \%$ and $1 \%$ level of significance. Therefore, the result depict that there is a significant difference between the urban and rural trained teachers. This result leads to the conclusion that the urban trained teachers are little aware in contrast to rural trained teachers. The obtained result is quite logical as urban teachers get facilities either formally or no formally related to ICT.

Major Findings

The trained teachers had $4 \%$ very poor, $54 \%$ poor, $34.33 \%$ average, $2 \%$ good and $5.66 \%$ very good level of ICT awareness. teachers.

There was no significant difference in the level of ICT awareness among the male and female trained

There was a significant difference between the urban and rural trained teachers. The urban trained teachers were little aware in contrast to rural trained teachers.

Educational Implications

This study will helpful to launch the ICT based ethnicity among the teachers.

It will stimulate the educational planners to start a revolution in the whole educational system to introduce uniform ICT based curriculum in different University.

\section{Conclusion}

Traditional methods of teaching could never develop plan effective foundation for critical thinking and understanding for the students. They could learn more when learning became personal and it is only possible by using Information Communication Technology in class room situation. Through it the learners would be able to construct their own concept and find their own solutions to their problems. It will be more possible only when teachers will have adequate knowledge and awareness regarding ICT. The teachers should be given appropriate training for inculcating skills associated to ICT for its awareness. It is expected that if the teachers are fully aware, they will be able to guide their learners for their bright future. 


\section{References}

[1]. Adebowale, O. F. (2012). Teachers'Awareness of Nigeria's Educational Policy on ICT and the use of ICT in Oyo State Secondary Schools. International Journal of Computing and ICT Research, 6 (1), 84-93, retrieved from http://www.ijcir. org/volume6number1/article9.pdf.

[2]. Beena, \& Mathur, M. (2012). A Study on the ICT Awareness of M.Ed. Trainees. International Journal of Business Management \& Economic Research, 13 (4), 573-578.

[3]. Best, J. W., \& Kahn, J. V. (2007). Research in Education (9th ad.). New Delhi: Prentice Hall of India Private Limited.

[4]. Bhattacharya, I., \& Sharma, K. (2007). India in the knowledge economy - an electronic paradigm. International Journal of Educational Management, 21(6), 543-568.

[5]. Brown, N. T., McCormac, M., Zimmermann, R. (2009). An Analysis of the Research and Impact of ICT in Education in Developing Country Contexts. Journal of Education for International Development, 4 (2), 12.

[6]. Conole, C. (2004). E-learning: The Hype and the Reality. Journal of Interactive Media in Education, retrieved from http://www-jime.open.ac.uk/2004/12/conole-2004-12.pdf.

[7]. Cross, M., \& Adam, F. (2007). ICT Policies and Strategies in Higher Education in South Africa: National and Institutional Pathways. Higher Education Policy, 20 (1), 73-95.

[8]. Dash, M. K. (2007). Integration of ICT in teaching Learning: A challenges. Edutract, 6 (12), 11-13.

[9]. Elizabeth, E.T.(2010). Inculcating Technological Know-how and Integrating ICT in Curriculum in the Teaching-learning Process. Indian Educational Review, 47 (2),115-130.

[10]. Eng, T. S. (2005). The impact of ICT on learning: A review of research. International Education Journal, 6 (5), 635-650.

[11]. Garrison, R., \& Anderson, T. (2003). E-Learning in the 21st Century: A Framework for Research and Practice. Routledge Falmer, London, retrived from http://www.goodreads.com/review/show/917767.

[12]. Geer, R., \& Sweeney, T. (2012). Students' Voices about Learning with Technology. Journal of Social Sciences, 8 (2), 294

[13]. Gulhane, G. L. (2011). Integrating ICT in Teacher Education, MIER. Journal of Educational Studies, Trends and Practices, 1(2).

[14]. Jaffer, S., Dick Ng'ambi, D., \& Laura, C. (2007). The role of ICTs in higher education in South Africa: One strategy for addressing teaching and learning challenges. International Journal of Education and Development using Information and Communication Technology, 3 (4), 131-142.

[15]. Jaiswal, D. (2011). Role of ICT in Teacher Education. Edutract,10 (11), 9-10.

[16]. Kay, R. H. (2006). Evaluating strategies used to incorporate technology into pre-service education: A review of the literature. Journal of Research in Technology in Education, 38 (4), 383-408.

[17]. Khedekar, S. M., \& Magre, S. (2012). A Study of Information and Communication Technology Awareness and Academic Performance of Secondary Students. International Educational E-Journal, 1 (3).

[18]. Mangal, S. K. (2007). Statistics in Psychology and Education. New Delhi: Prentice-Hall of India Private Limited.

[19]. Muthuchamy, I. (2010). Higher secondary students' perception towards ICT. Jornal of Educational Research and Extension, SRMVCE, 47 (1).

[20]. National Curriculum framework. (2005). New Delhi: NCERT.

[21]. Oye, N. D., Shallsuku, Z. K., \& Iahad, A. N. (2012). The Role of ICT in Education: Focus on University Undergraduates learners. International Journal of Advanced Computer Science and Applications, 3 (2), 136-143.

[22]. Plomp, T., Pelgrum, W. J., \& Law, N. (2007). SITES 2006-International comparative survey of pedagogical practices and ICT in education. Education and Information Technologies 12 (2), 83- 92.

[23]. Price, S., \& Oliver, M. (2007). A Framework for Conceptualising the Impact of Technology on Teaching and Learning. Educational Technology \& Society, 10 (1), 16-27.

[24]. Rajasekar, S., \& Dineshan, P. (2013). The ICT knowledge of B.Ed. students. International Journal of Teacher Educational Research, 2 (5).

[25]. Rathnabai, A. (2007). Infusing ICT in teaching learning process: A Reflection. International Seminar held at Periyar University. Brown, N. T., McCormac, M., \& Zimmermann, R. (2009). An Analysis of the Research and Impact of ICT in Education in Developing Country Contexts. Journal of Education for International Development, 4 (2), 12.

[26]. Sasikala, V. H. (2010). ICT Awareness of B.Ed Trainees. Journal of Information Science, 26 (6).

[27]. Swamy, A. M. (2010). Internet awareness and competence among high school students and teacher. Edutract, 9 (7), $41-43$.

[28]. Vajargah, K. F., Jahani, S., \& Azadmanesh, N. (2010). Application of ICTs in Teaching and Learning at University Level: The Case of Shahid Beheshti University. The Turkish Online Journal of Educational Technology, 9 (2), 33-39.

[29]. Wang, S. K., McPherson, S., Hsu, H.Y., \& Tsuei, M. (2008). Information and communication technologies to develop teachers' global awareness. International Journal of Education and Development using Information and Communication Technology, 4 (2), 89-104.

[30]. Yuen, A., Law, N., \& Wong, K. (2003). ICT implementation and school leadership Case studies of ICT integration in teaching and learning. Journal of Educational Administration, 41 (2), 158-170.

[31]. Yusuf, M.O. (2005). Information and communication education: Analyzing the Nigerian national policy for information technology. International Education Journal, 6 (3), 316-321. 